\title{
Review of Sadow, Lauren, Bert Peeters, and Kerry Mullan (eds.). 2020. Studies in Ethnopragmatics, Cultural Semantics, and Intercultural Communication: \\ Vol. 3. Minimal English (and beyond). Singapore: Springer. ISBN 978-981-329-978-8
}

\section{Anna GLADKOVA}

Monash University / Australian National University Australia

For citation:

Gladkova, Anna. 2020. Review of Sadow, Lauren, Bert Peeters, and Kerry Mullan (eds.). 2020. Studies in Ethnopragmatics, Cultural Semantics, and Intercultural Communication: Vol. 3. Minimal English (and beyond). Singapore: Springer. ISBN 978-981-329-978-8. Russian Journal of Linguistics 24 (4). 1049-1054. DOI: 10.22363/2687-0088-2020-24-4-1049-1054

Рецензия

\section{Рецензия на книгу}

Sadow, Lauren, Bert Peeters, and Kerry Mullan (eds.). 2020. Studies in Ethnopragmatics, Cultural Semantics, and Intercultural Communication: Vol. 3. Minimal English (and beyond). Singapore: Springer. 309 c.

\author{
А. ГЛАДКОВА \\ Университет Монаш / Австралийский национальный университет \\ Австралия
}

Для цитирования:

Gladkova A. Review of Sadow, Lauren, Bert Peeters, and Kerry Mullan (eds.). 2020. Studies in Ethnopragmatics, Cultural Semantics, and Intercultural Communication: Vol. 3. Minimal English (and beyond). Singapore: Springer. ISBN 978-981-329-978-8. Russian Journal of Linguistics. 2020. Vol. 24. № 4. P. 1049-1054. DOI: 10.22363/2687-0088-2020-24-4-1049-1054

Studies in Ehtnopragmatics, Cultural Semantics, and Intercultural Communication is a set of three volumes published by Springer in 2020 and edited by Bert Peeters, Kerry Mullan, and Lauren Sadow. ${ }^{1}$ They celebrate the career and

\footnotetext{
${ }^{1}$ The order of the authorship varies in different volumes.
} 
achievements of Cliff Goddard, a Professor of Linguistics at Griffith University (Australia). Along with Anna Wierzbicka, Cliff Goddard is known as a pioneer and developer of the Natural Semantic Metalanguage (NSM) approach in linguistics. Encompassing the breadth of the approach, the volumes bear the subtitles:

Ethnopragmatics and Semantic Analysis (Vol. 1) (Mullan et al. 2020),

Meaning and Culture (Vol. 2) (Peeters et al. 2020),

Minimal English (and Beyond) (Vol. 3) (Sadow et el. 2020).

This review focuses on the third volume of the set which is dedicated to the latest development of the approach known as Minimal English (or Minimal Language). Minimal English is rooted in the Natural Semantic Metalanguage and aims to enlarge its potential in areas beyond linguistics.

NSM is an evidence-based approach in linguistic analysis which claims that linguistic meaning can be formulated using mainly sixty-five universal, semantically simple and empirically identified meanings (Goddard 2018a, Goddard and Wierzbicka 2002, 2014, see Gladkova and Larina 2018a, 2018b for an overview). The idea is based on Leibniz's hypothesis that each language has a core vocabulary (named by him "the alphabet of human thought") which cannot be defined further. The empirical testing of various types of vocabulary was started by Wierzbicka to explore this hypothesis and was later supported and enriched by Goddard's contribution, along with contributions from other scholars. In the current form, the NSM comprises a fully-developed metalanguage of sixty-five semantic universals and their governing syntax. It has been successfully used for writing explications (formulas representing meaning of lexemes or expressions) and cultural scripts (short texts capturing cultural norms underlying linguistic practices). The branches of linguistics associated with this approach became known as Cultural Semantics and Ethnopragmatics. The NSM has proven to be highly successful in a comparative cross-linguistic and cross-cultural analysis.

A more recent development of the NSM approach became known as Minimal English (or Minimal Language). In her 2014 book Imprisoned in English (2014) Anna Wierzbicka introduced the idea that the potential of the NSM (with the principle of reductive paraphrase and limited vocabulary for definitions) could serve broader communities and be applied in other discipline studies in its expanded version.

This idea was later discussed and developed at a symposium on the topic held at the Australian National University in 2014. The first publication on Minimal English was Minimal English for a global world: Improved communication using fewer words (Goddard 2018b). In this edited collection of works, linguists, along with specialist in other disciplines, address the potential of Minimal English in areas such as the media, science communication, applied sciences, and the defence of human rights.

The 2020 celebratory volume is a brilliant representation of the Minimal English in linguistics and relating areas. Its content can be broadly summarised into the following areas: language and culture pedagogy (Chapters 2, 7, 9, 11), 
communication in the situation of limited language knowledge (Chapters 3,11 ), conceptual and semantic analysis for the purpose of successful communication in the areas of personal relations, attitudes, colour studies and others (Chapters 4, 5, 6 ), and explorations in neurodiversity (Chapter 8). Across the volume, Minimal English is used to construct explications, cultural scripts, as well as short texts to represent meaning or ideas. Other linguistic issues dealt upon in this volume include cross-linguistic and cross-cultural analysis (Chapter 4, 5), diachronic semantic change (Chapter 6), conceptual variation in language varieties (Chapters 3 and 7), and dictionary making (Chapters 9 and 10). The content of the volume can be summarised as follows.

Lauren Sadow in Chapter 1 compares NSM and Minimal English and justify describes the content of the volume. She discusses the potential of Minimal English in different areas.

Susana S. Fernández (Chapter 2) identifies gaps in major Spanish teaching textbooks in Denmark and explores how NSM and Minimal English can bridge those gaps. The chapter includes her analysis of practical application of NSM in intercultural training at university level and contains examples of practical activities in educational process. Fernández argues for a greater potential of Minimal English in teaching intercultural communication.

Deborah Hill (Chapter 3) identifies the Minimal English potential in the situation of agricultural training in PNG. While the training is being conducted in English, the detailed context is not always well understood by local participants due to poor knowledge of English as well as the influence of the local vernacular language. This misunderstanding is two-way as participants can be using English sounding words in their localized meanings which are not accessible and known to trainers. By way of example of such misunderstanding, Hill provides a detailed discussion of the three lexemes of the verb to brainstorm: 1) to brainstorm ideas (mainstream English), 2) brainstorm first and 3) brainstorm me (the two latter are local uses). With the help of Minimal English she explicates the three meanings in question and demonstrates how Minimal English could be effective in the explanation of project-related ideas and concepts. She also proposes explications for story and case study which are used in training and have different cultural value for the participants and the presenters. Hill concludes with the importance of using Minimal English in the situation of multicultural training.

The chapter by Anna Wierzbicka and Anna Gladkova (Chapter 4) explores the meaning of sex in a cross-linguistic and cross-cultural perspective. It overviews possible differences in its conceptualisation across European languages and then focuses on the meanings of the words in question in English and Russian. Drawing on corpora data the study identifies similarities and differences between Russian and English lexemes. One of possible linguistic reasons for the differences is the variation in the collocation profiles of the expressions. The results suggest that the Russian expression implies a greater degree of involvement. Hypothetically, this is consistent with broader cultural themes relating to emotion expression. 
Anna Gladkova's research (Chapter 5) deals with the situation of linguistic borrowing in modern Russian. In particular, she looks at the assimilation of the term tolerantnyj 'tolerant' in Russian. The history of the term appears to be closely linked with the country's history and ideological turns. The term was first used in the $19^{\text {th }}$ century, but fell out of use in the Soviet times. It became relevant during Perestroika under the influence of Western ideas. The chapter observes a certain 'adaptation' and 'adjustment' of the meaning compared to its source meaning in English. The adaptation is largely explained by the existence terms with close meaning and overall influence of cultural ideas and themes. Minimal English serves as an effective tool in explaining this concept which potentially could be useful in communicating ideas of social attitudes across disciplines.

Jiashu Tao and Jock Wong (Chapter 6) explore the meaning of the Mandarin colour term qing in a diachronic perspective applying Minimal English. In particular, they analyse the polysemy of qing and trace its meaning in different periods. Being regarded as an equivalent of blue, black, and green in English, the meaning of the term is shown to change from a non-colour term to a colour term and to a non-colour term again but with different meanings. Minimal English proves to be an effective tool in the description of the richness of the meanings embedded in qing.

Jock Wong (Chapter 7) discusses the issue of linguistic conceptualisation in the context of the complex situation of linguistic diversity in Singapore. In particular, he demonstrates using the examples of his students' work that their understanding of certain English terms (hypothesis, theory, and proof) differs from their actual meaning in an academic context. He reports on his use of Minimal English to teach them how to think about and break down the concepts, before writing Minimal English explications to clarify their exact meaning.

Alex Forbes (Chapter 8) illustrates the use of Minimal English in the conceptualisation of neurodiversity. In particular, relying on data from crosscountry sources he summarises how parents think about their autistic children and how they reflect on their experiences as parents. Minimal English proves to be an effective tool to describe group cognition, allowing us to understand more about perspectives on neurodiversity.

The chapter by Lauren Sadow (Chapter 9) is about creating a cultural dictionary for learners of English as a second language. In this dictionary, Minimal English becomes the instrument which is able to capture ethnopragmatic norms and cultural values in a culture-neutral and restricted metalanguage. She discusses the challenges of structuring a dictionary without alphabetical ordering of entries.

María Auxiliadora Barrios Rodriguez (Chapter 10) discussed the role of Minimal English in creating effective dictionary definitions. Based on her experience, she acknowledges that recognition of a description of a concept does not involve using all the aspects of semantic explications practiced in NMS. She reports on creating 'minimal and inverse definitions' and uses statistical methods in identifying the level of recognition of a definition by native speakers. This 
research is part of a university project and demonstrates how post-graduate research students can be effectively involved in such lexicographic explorations.

Ulla Vanhatalo and Camilla Lindholm (Chap. 11) discuss a significant role that Minimal English can play in creating texts within the easy-to-read movement. They report on a growing role of such movement in some European countries in the context of the increase of groups of people with limited abilities for reading (migrants as well as people with learning disabilities or cognitive decline). Within a pilot project, the authors identify the prevalence of the NSM semantic primes in easy-to-read texts and discuss the potential of Minimal English in the easy-to-read movement.

The volume closes with an exhaustive list of Cliff Goddard's publications to date in a chronological order.

The book is a brilliant collection of state-of-the art research in NSM and Minimal English. It significantly advances explorations of the potential of Minimal English (or Minimal Language) in linguistics and other areas. It successfully demonstrates how Minimal English can be used in language and culture pedagogy, dictionary making, conceptual analysis and communication, understanding neurodiversity and group cognition.

(C) Anna Gladkova, 2020

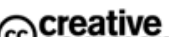
@creative

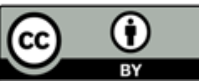

This work is licensed under a Creative Commons Attribution 4.0 International License https://creativecommons.org/licenses/by/4.0/

\section{REFERENCES}

Gladkova, Anna \& Tatiana Larina. 2018a. Anna Wierzbicka, words and the world. Russian Journal of Linguistics 22 (3). 499-520. doi: 10.22363/2312-9182-2018-22-3-499-520.

Gladkova, Anna \& Tatiana Larina. 2018b. Anna Wierzbicka, culture and text. Russian Journal of Linguistics 22 (4). 717-748. .doi: http://dx.doi.org/10.22363/2312-9182-2018-22-4717-748.

Goddard, Cliff. 2018a. Ten Lectures on Natural Semantic Metalanguage: Exploring language, thought and culture using simple, translatable words. Leiden: Brill.

Goddard, Cliff (ed.). 2018b. Minimal English for a Global World: Improved Communication Using Fewer Words. London: Palgrave Macmillan.

Goddard, Cliff \& Anna Wierzbicka. 2014. Words and Meanings: Lexical Semantics Across Domains, Languages, and Cultures. Oxford: Oxford University Press.

Goddard, Cliff \& Anna Wierzbicka (eds.). 2002. Meaning and Universal Grammar: Theory and empirical findings. Vols. I, II. Amsterdam: John Benjamins.

Mullan, Kerry, Bert Peeters \& Lauren Sadow (eds.). 2020. Studies in Ethnopragmatics, Cultural Semantics, and Intercultural Communication: Vol. 1. Ethnopragmatics and Semantic Analysis. Singapore: Springer.

Peeters, Bert, Kerry Mullan \& Lauren Sadow (eds.) 2020. Studies in Ethnopragmatics, Cultural Semantics, and Intercultural Communication: Vol. 2. Meaning and culture. Singapore: Springer. 
Sadow, Lauren, Bert Peeters \& Kerry Mullan (eds.). 2020. Studies in Ethnopragmatics, Cultural Semantics, and Intercultural Communication: Vol. 3. Minimal English (and beyond). Singapore: Springer.

Wierzbicka, Anna. 2014. Imprisoned in English: The hazards of English as a default language. New York: Oxford University Press.

\section{Book review history:}

Received: 1 August 2020

Revised: 25 October 2020

Accepted: 27 October 2020

\section{История рецензии:}

Дата поступления в редакцию: 1 августа 2020

Дата принятия к печати: 27 октября 2020

\section{Bionote}

Anna GLADKOVA is a Lecturer на an Adjunct Research Fellow in English as an International Language at Monash University and an Honorary Lecturer in Linguistics at the Australian National University. She received her $\mathrm{PhD}$ in Linguistics from the Australian National University. Her research interests include semantics, pragmatics, language and culture interface, cognitive linguistics and Natural Semantic Metalanguage. She has taught linguistics and applied linguistics at the Australian National University and University of New England (Australia) as well as University of Sussex and University of Brighton (United Kingdom). She is member of the Editorial Board of Corpus Pragmatics and Yearbook of Corpus Linguistics and Pragmatics (Springer).

\section{Contact information:}

20 Chancellors Walk, Clayton Campus, Monash University, Melbourne VIC 3800, Australia

e-mail: angladkova@gmail.com

\section{Сведения об авторе:}

Анна ГЛАДКОВА получила докторскую степень по лингвистике в Австралийском национальном университете. Она преподает на внештатный научный сотрудник в Университете Монаш (Австралия), а также является почетным преподавателем лингвистики в Австралийском национальном университете. Ее научные интересы включают семантику, прагматику, взаимодействие языка и культуры, когнитивную лингвистику и Естественный Семантический Метаязык. Она преподавала лингвистику и прикладную лингвистику в Австралийском национальном университете и Университете Новой Англии (Австралия), а также в Университете Сассекса и Университете Брайтона (Великобритания). Является членом редколлегии журнала «Корпусная Прагматика» и «Ежегодника по корпусной лингвистике и прагматике» (издательство Springer).

\section{Контактная информация:}

20 Chancellors Walk, Clayton Campus, Monash University, Melbourne VIC 3800, Australia e-mail: angladkova@gmail.com 